\title{
住民参加型の道空間づくりにおける合意形成のプロセスについて*
}

\section{The Process of the Agreement on Street Space Planning by the Residents*}

江夏量 $* *$. 外井哲志 $* * *$. 坂本紘二 $* * * *$. 㐘池康昭 $* * * * *$ - 梶田佳孝 $* * * * * *$. 末久正樹******** By Ryo ENATSU** · Satoshi TOI*** Koji SAKAMOTO**** • Yasuaki KIKUCHI***** Yoshitaka KAJITA******* Masaki SUEHISA*******

\section{1.はじめに}

住民参加とは、環境または公共施設のあり方によって 最も影響を受ける住民が、その決定プロセスに参画する ことである。

住民参加型の生活道路整備に関する研究として、浦

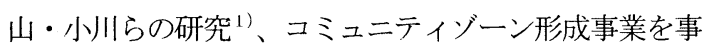
例とした研究として山岡・磯部の研究 ${ }^{2)}$ 、花田・川村ら の研究 ${ }^{3)}$ が挙げられるが、これらはいずれも事業後の意 識調査結果の評価・分析により、各種対策による効果や 意識変容、問題点を指摘するものである。

住民参加の問題は合意形成が中心課題であり、これを 明らかにするためには、合意に至った協議プロセスの事 例分析を積み重ねる必要がある。さらに長期的な協議ブ ロセスを含んだ記録を綿密に追うことができれば好まし いが、こうした研究例は極めて少ないのが現状である。

本研究では、福岡市南区若久地区コミュニティゾーン 形成事業を事例として、長期に渡つて重ねられた調整協 議会のプロセスを、協議会議事録の整理を主たる手段と しヒアリングを補助的に用いて把握することで、住民参 加のプロセスがどのように進行し、また対立点に対し合 意形成がどのように図られたかを分析した。さらに、合 意形成の促進に必要な条件を示すと共に、進行上の課題 を明らかにし改善の方策を提案した。

\section{2. 若久地区コミュニティゾーン形成事業の概要}

コミュニティゾーン形成事業は、高齢者や児童・生徒 の交通事故の急増を受け、それに対応するため、事故多 発地帯における対策を重点的に行うなど事故特性等に即

*キーワーズ : 市民参加、地区交通計画

**学生会員、九州大学工学府都市環境システム工学専攻(テ812-8581 福岡市 東区箱崎 6-10-1 Tel092-641-3131 E-mail:enatsu@doc.kyushu-u.ac.jp) ***正会員、工博、九州大学助教授、工学研究院環境都市部門( 岡市東区箱崎 6-10-1 Tel092-642-3277)

****正会員、工修、下関市立大学教授 $(=751-0831$ 下関市大学町 $2 \cdot 1 \cdot 1$ Tel0832-52-0288)

*****非会員、北九州市建設局西部整備事務所( 区西曲里町 2-1 黑崎テクノプラザ4F Tel093-642-5434)

******正会員、工博、九州大学助手、工学研究院環境都市部門

*******学生会員、九州大学工学府都市環境システム工学専攻
した交通安全施設等を整備することを目的とした国土交 通省の補助事業であり、本事業の特徵として以下の 4 点 が挙げられる。

(1)面的な範井設定による施策の計画的・効率的実施

(2)ソフト手法と八ード手法の組み合わせによる整備効果 の向上

(3)総合的な体制で取り組むことによる合意形成の円滑化 や地区特性の反映

(4)総合的な視点に配慮し多様な目的一対応する

\section{（1）若久地区の選定理由}

福岡市南区ではコミュニティゾーン形成事業の対象地 区として 5 つの地区が候補地に挙がった。その 5 地区に ついて、マニュアル 45)に従って福岡市土木局が実施にあ たり示した(1)〜(5)の基本方針に基づいて比較検討した結 果、若久地区が選定されることとなった。

(1)整備された幹線道路で囲まれた地区であること。

若久地区は、北を塩原野間線、東を野間屋形原線、そ して西を大池通りという3 本の整備された幹線道路で囲 まれた地区である。

(2)通過交通の流れ込みが多い地区であること。

若久地区は、朝の通勤時には、地区の北側と西側の幹 線道路から大量の通過交通が進入し、同時間帯に通学寸 る小・中学生、散歩する高齢者が大変危険を感じており、 通過交通の排除が最も必要な地区の一つである。

(3)コミュニティ道路や歩車共存道路等のメインとなる道 路整備ができる地区であること。

若久地区は、後述するふれあいロード、オアシスロー ド等の主要な道路が周囲の幹線道路相互を結んでおり、 これらの道路を対象としてコミュニティ道路や歩車共存 道路等の道路整備ができる地区である。

(4)既に通過交通抑制のための交通規制がなされている地 区であること。

若久地区は、通過交通抑制のための時間帯規制を実施 していたが、なかなか効果が現れていない状況であった。 (5)地元の協力が得やすい地区であること。

若久地区には、「若久サミット」というまちづくり組織 があり、地元の協力が得や寸い地区であった。

本事業のような参加型の社会基盤整備には、多くの自 


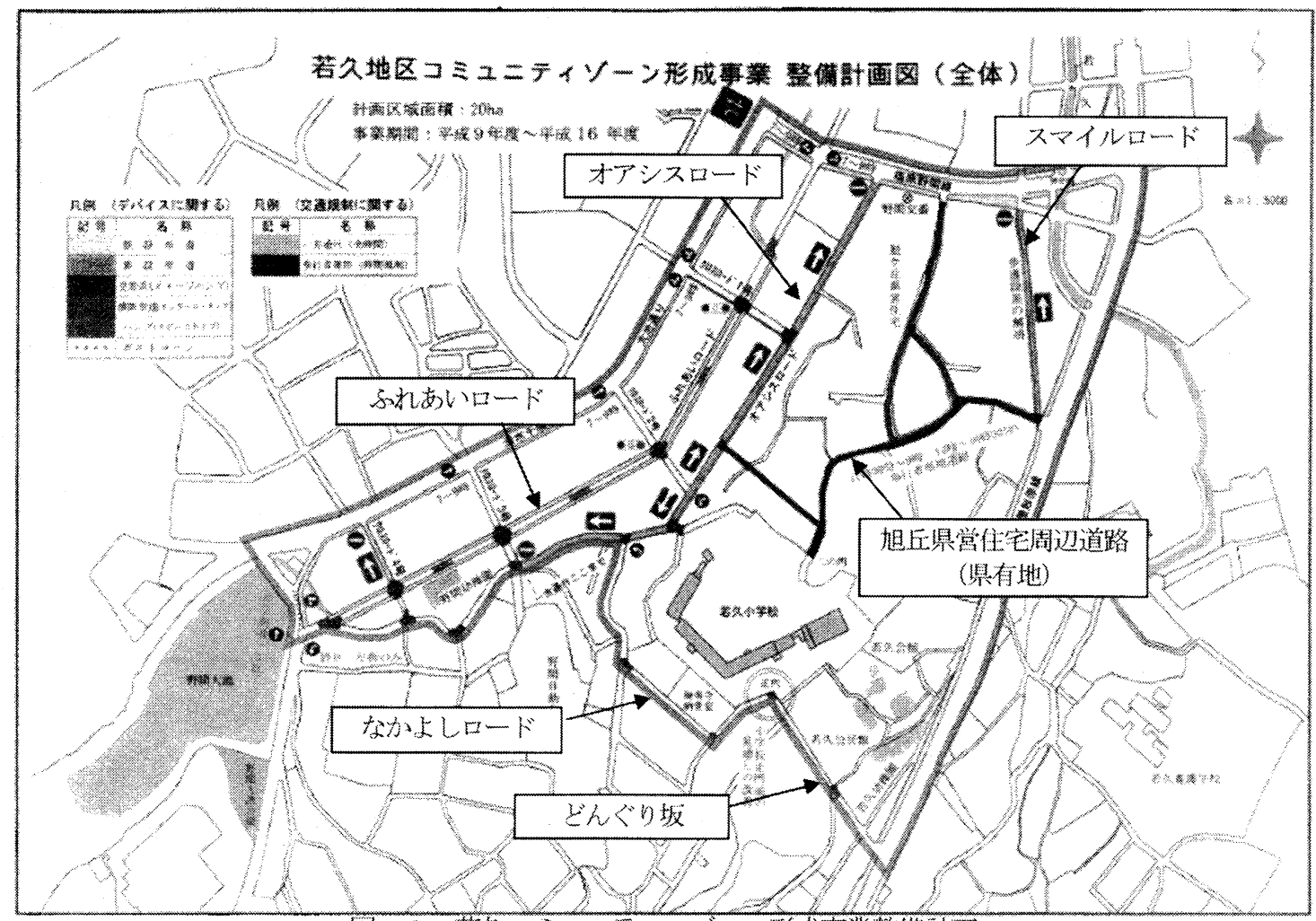

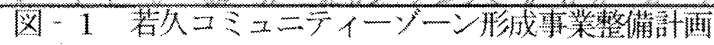

発的·積極的な住民の参加が必要である。また、道空間の 整備ということもあり、様々な利害関係が絡んでくる。 事業を円滑に行うために、ある程度地域のコミュニティ が成り立ち、自治活動が盛んな中で利害調整が進むこと が望まれる。若久地区がこの(5)の条件を満たしていたこ とが、本事業に選定された最大の要因であった。

\section{（2）整備内容}

若久コミュニティーゾーン形成事業の整備内容を以下 に示す。図一 1 は最終的な整備計画図である。

(1)ふれあいロード

若久地区内の主要道路である (図-1)。事業以前に一 応の整備が完了しており、今回の整備では交差点にイメ ージハンプと道路 4 䇢所にスピードセーブ工法がなされ た(図-2)。

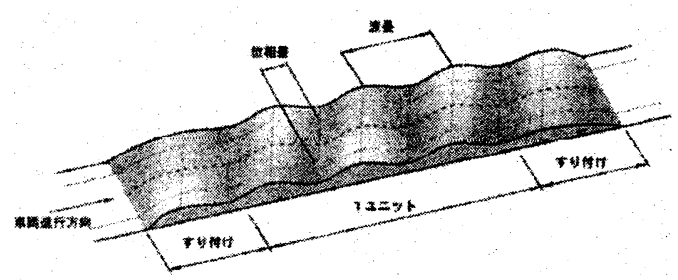

図ー2 スピードセーブ工法
(2)オアシスロード

この地区内のもう一つの主要道路であり、また通過車 両が使用する道路でもあった（図一 1 )。写真一 1 は整備 前と整備後を比較したものである。電柱が統合整備され、 さらに歩車道境界上に設置されることで、歩車道の分離 が明確になっている。

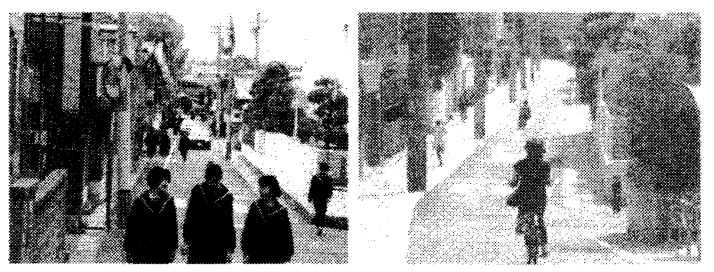

写真一 1 オアシスロード整備前と整備後

(3)どんぐり坂、なかよしロード

若久小学校前の道路であり、小学生が名付けた道路で ある。歩道がカラー舗装化、交差点がイメージハンプと された（図一1）。

(4)スマイルロード

段差が解消され、歩道がカラー化された（図一1）。

(5)旭ヶ丘県営住宅周辺 (県有地譲渡問題)

県有地を譲渡してもらい、歩車共存道路と時間帯歩行 者専用道路の整備を行う計画であるが、手続き等に時間 を要し、すぐには着工できない状況である(図ー1)。よっ て今後の状況を見ながら整備を進めていくことになった。 
表 - 2 協議会議事録から整理できた協議会の経緯の概略

\begin{tabular}{|c|c|c|c|c|}
\hline ステージ & 回数 & 概要 & 主な内容 & 備考 \\
\hline \multirow{6}{*}{$\begin{array}{l}\text { 1. 基本構想·代 } \\
\text { 替案づくり } \\
1998.2 \sim 1998.8\end{array}$} & $\begin{array}{c}\text { 第0回 } \\
1997.9 .29\end{array}$ & \begin{tabular}{c|} 
交通安全絃 \\
点傼
\end{tabular} & 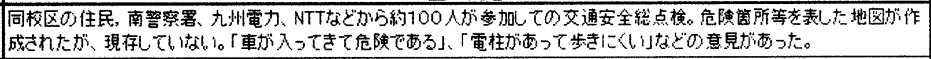 & \\
\hline & $\begin{array}{c}\text { 第1回 } \\
1998.225\end{array}$ & 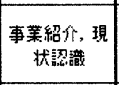 & 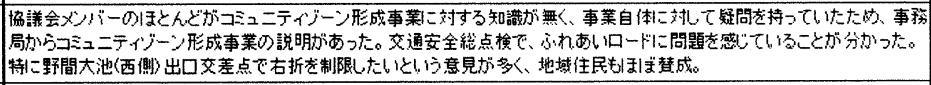 & \\
\hline & $\begin{array}{c}\text { 第2回 } \\
1998.4 .15\end{array}$ & \begin{tabular}{|l|} 
事稀局力50 \\
調查結果啹告 \\
\end{tabular} & 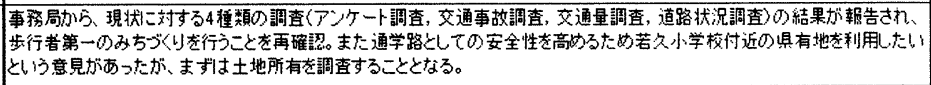 & \\
\hline & $\begin{array}{c}\text { 第3回 } \\
1998.63\end{array}$ & 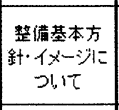 & 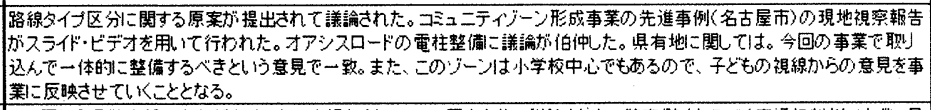 & \\
\hline & $\begin{array}{c}\text { 第4回 } \\
1998.7 .1\end{array}$ & \begin{tabular}{|c|} 
文通規制案に二 \\
$\supset, 1, \tau$ \\
\end{tabular} & 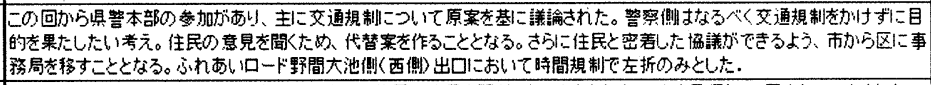 & \\
\hline & $\begin{array}{c}\text { 第5回 } \\
1998.8 .6 \\
\end{array}$ & $\begin{array}{c}\text { 案の职りまと } \\
\text { め) }\end{array}$ & 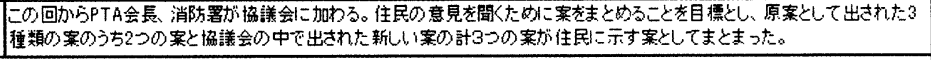 & 3つ0代替案 \\
\hline $\begin{array}{l}\text { 全町民䋨会、3町内 } \\
\text { による合同説明会 } \\
1998.9 .29\end{array}$ & \multicolumn{3}{|c|}{ 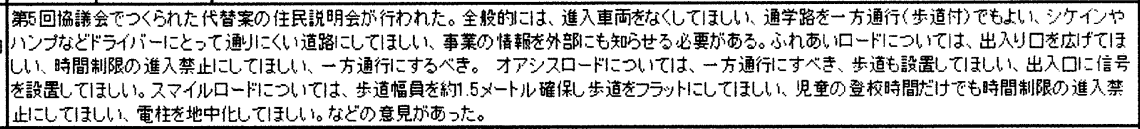 } & \\
\hline \multirow{3}{*}{$\begin{array}{l}\text { 2. 基本案づくり } \\
1998 \text { 10 1999.3 }\end{array}$} & \begin{tabular}{c|} 
第6回 \\
1998.10 .21
\end{tabular} & $\begin{array}{c}\text { 地元意見の集 } \\
\text { 約 }\end{array}$ & 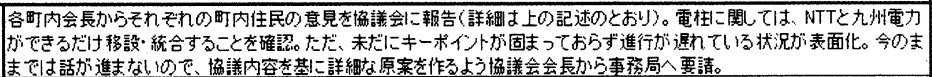 & \\
\hline & \begin{tabular}{c|c} 
第洄 \\
1998.1125 \\
\end{tabular} & \begin{tabular}{c|} 
一本化した案 \\
0 换討
\end{tabular} & 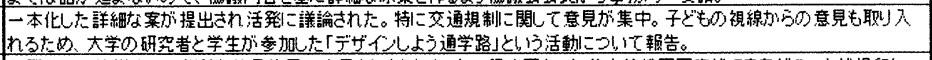 & \\
\hline & $\begin{array}{c}\text { 第回 } \\
1999.3 .10\end{array}$ & \begin{tabular}{c|c|} 
基本方針まと \\
加・答
\end{tabular} & 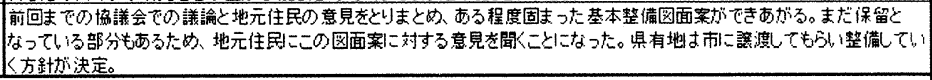 & $\begin{array}{l}\text { 整備計画基本案 } \\
\text { D決定 }\end{array}$ \\
\hline $\begin{array}{c}\text { 住民説明会 } \\
1999.57 \\
\end{array}$ & \multicolumn{3}{|c|}{ 行政側の協議会メハバーも出席しての住民説明会が行われたとの記緑が残っていたが、詳細内容についての記録は現存せず。 } & \\
\hline \multirow{5}{*}{$\begin{array}{l}\text { 3. 実施案-3<り } \\
1999.6 \sim 2000.6\end{array}$} & $\begin{array}{c}\text { 第9回 } \\
1999.64\end{array}$ & 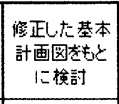 & 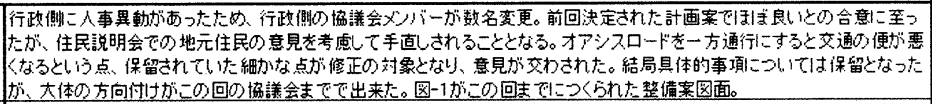 & \\
\hline & $\begin{array}{l}\text { 第10回 } \\
1999.7 .21\end{array}$ & 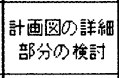 & 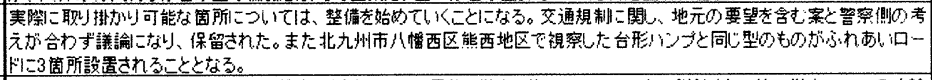 & \\
\hline & \begin{tabular}{|c|} 
第11回 \\
1999.11.17
\end{tabular} & \begin{tabular}{|l|} 
オアシスロード \\
の歩車道境界 \\
\end{tabular} & 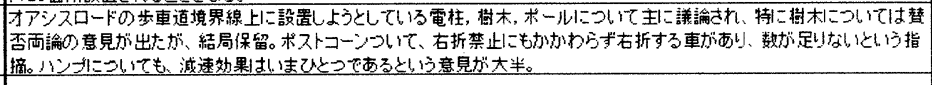 & 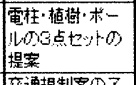 \\
\hline & $\begin{array}{c}\text { 第12回 } \\
2000.1 .26\end{array}$ & 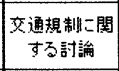 & 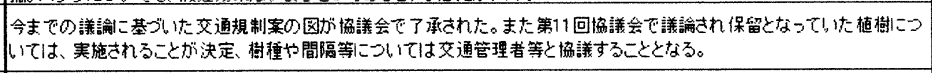 & 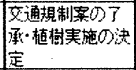 \\
\hline & $\begin{array}{l}\text { 第13回 } \\
20006.22\end{array}$ & \begin{tabular}{|c|c|c|} 
交通規制の最 \\
終確認 \\
\end{tabular} & 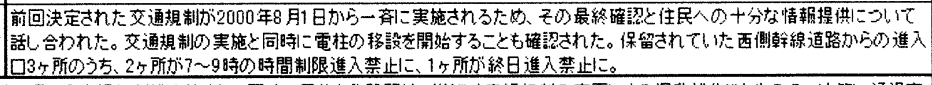 & 電挂の移設決定 \\
\hline $\begin{array}{l}\text { 畕議者に対する } \\
\text { 説明会 } \\
20009.11\end{array}$ & \multicolumn{3}{|c|}{ 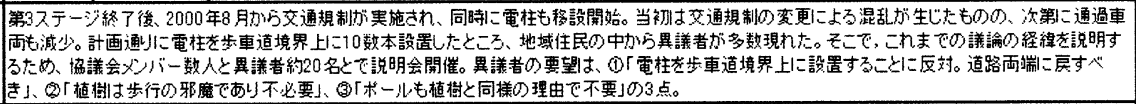 } & 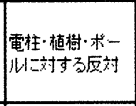 \\
\hline \multirow{4}{*}{$\begin{array}{l}\text { 4. 異議者との)議論 } \\
2000 \sim 201.4\end{array}$} & $\begin{array}{l}\text { 第14回 } \\
2000.9 .27\end{array}$ & $\begin{array}{l}\text { 異議者を交え } \\
\text { ての討論(1) }\end{array}$ & 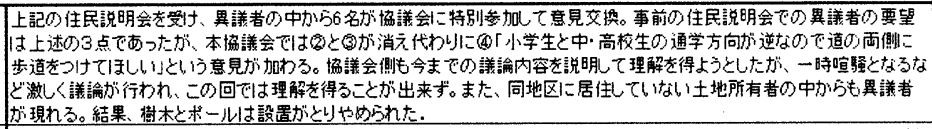 & 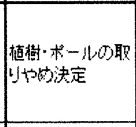 \\
\hline & $\begin{array}{c}\text { 第15回 } \\
2000.1129\end{array}$ & $\begin{array}{l}\text { 異議者京交え } \\
\text { ての討謪(2) }\end{array}$ & 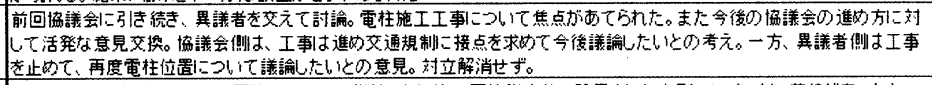 & \\
\hline & $\begin{array}{l}\text { 第16回 } \\
2001.2 .7 \\
\end{array}$ & $\begin{array}{l}\text { 要望書に詨す } \\
\text { る文書回答 } \\
\end{array}$ & 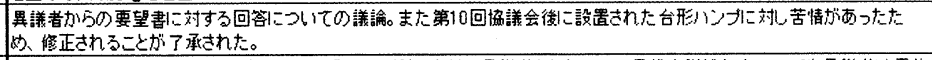 & $\begin{array}{l}\text { 台形八ソグに苦 } \\
\text { 情・改良を決定 }\end{array}$ \\
\hline & $\begin{array}{l}\text { 第17回 } \\
2001.4 .2\end{array}$ & $\begin{array}{l}\text { 異議者を交え } \\
\text { ての討論(3) }\end{array}$ & 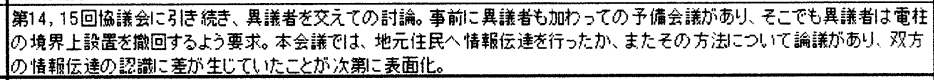 & $\begin{array}{l}\text { 情啹伝達に認識 } \\
\text { Ø差 }\end{array}$ \\
\hline \multirow{8}{*}{$\begin{array}{l}\text { 5. 施工計画·赛 } \\
\text { 施報告 } \\
2001.5 \sim 2003.9\end{array}$} & $\begin{array}{l}\text { 第18回 } \\
\text { 2001.5.21 } \\
\end{array}$ & $\begin{array}{c}\text { クロスロードの } \\
\text { 設計案 }\end{array}$ & $\begin{array}{l}\text { この回は議事緑がないが、(関保者ヒアリングによれば)オアシスロード、ふれあいロードと交差するクロスロードィ〜4号の設 } \\
\text { 計图面が提出され、これについて議論。 }\end{array}$ & \\
\hline & $\begin{array}{c}\text { 第19回 } \\
2001.828\end{array}$ & $\begin{array}{l}\text { スビードセーブ } \\
\text { エ法施工 }\end{array}$ & 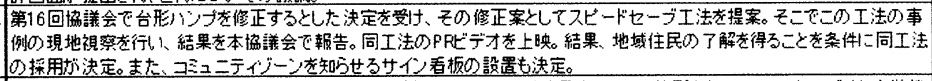 & 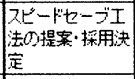 \\
\hline & $\begin{array}{l}\text { 第20回 } \\
2002.3 .25\end{array}$ & $\begin{array}{l}13 \text { 年度工事 } \\
\text { 完了報告・14 } \\
\text { 年度予定 } \\
\end{array}$ & 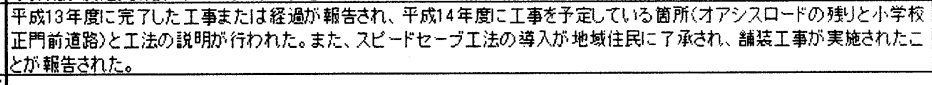 & \\
\hline & $\begin{array}{l}\text { 第21回 } \\
2002.5 .31\end{array}$ & $\begin{array}{l}\text { ․ーードセーブ } \\
\text { 工法の効果測 } \\
\text { 定結果 }\end{array}$ & 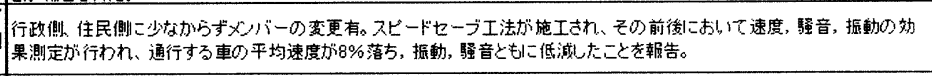 & \\
\hline & \begin{tabular}{|c|} 
第22回 \\
200210.11 \\
\end{tabular} & \begin{tabular}{|c|}
14 年度工事 \\
進撛状況
\end{tabular} & 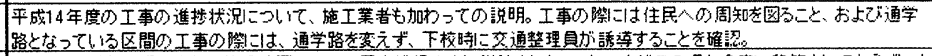 & \\
\hline & \begin{tabular}{|c|} 
第2.3回 \\
2003.2.19 \\
\end{tabular} & $\begin{array}{l}\text { 県有地周边道 } \\
\text { 路整槅計画 }\end{array}$ & 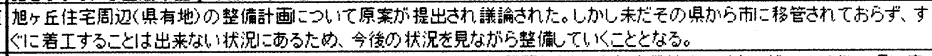 & \\
\hline & \begin{tabular}{|r|} 
第24回 \\
2003.6 .19 \\
\end{tabular} & $\begin{array}{c}15 \text { 年度工事 } \\
\text { 予定 }\end{array}$ & 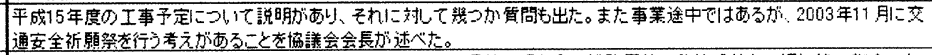 & \\
\hline & $\begin{array}{l}\text { 第26回 } \\
2003.9 .25\end{array}$ & $\begin{array}{l}15 \text { 年度笔注 } \\
\text { 工事 }\end{array}$ & 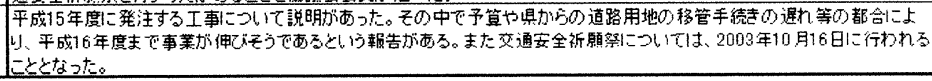 & \\
\hline
\end{tabular}




\section{3. 若久地区コミュニティゾーン形成事業調整協議会経 緯について}

\section{（1）協議会の発足とメンバーの構成}

地区選定後、1997 年 7 月にコミュニティゾーン形成事 業検討委員会が開催され、同年 12 月にはコミュニティゾ ーン形成事業調整協議会発足に向けて、地元の代表者や 交通規制に関わる者など、事務局がリストアップした構 成員予定者に協力を依頼した。協議会メンバーの構成を 表一 1 に示す。

協議会の会長には、協議会メンバーによって若久地区 のリーダー的存在である若久公民館の館長が、選出され ていた。これは今後の協議のスムーズな進行にとって望 ましい会長選出の形であった。

\begin{tabular}{|c|c|c|}
\hline 立場 & 所属 & 入数 \\
\hline 地元 & 公民館、自治連合会、町内会長、学校関係者等 & 13 名 \\
\hline 交通管理者 & 導䇾本部、南区謷察署 & 4 名 \\
\hline 消防 & 南区消防署 & 2 名 \\
\hline 道路管理者·南区役所 & 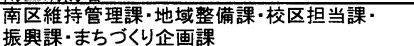 & 6名 \\
\hline 道路占用者 & 九州電力、NTTーネオメイト九州 & 4名 \\
\hline
\end{tabular}

※事務局は南区役所とワーキング(コンサルタント)で構成されている

\section{（2）協議会の開催の経緯}

若久地区コミュニティゾーン形成事業では、1998 年 2 月に開催された第 1 回協議会以降、現在 (2005 年 2 月) までの 7 年間で、延べ回数にして 28 回の協議会が開催さ れた。本研究では、第 25 回までの協議会議事録を収集し 整理することで、協議会経緯を把握するとともに事業全 体の流れを把握した。協議会議事録から整理できた協議 会の経緯の概略は表一2の通りである。なお、同表左端の ステージ区分は、協議会の進行を把握した後に著者らの 判断によって行ったものである。

第 1 ステージでは安全総点検や現状調査とその報告が 行われ、それらを通して基本構想・代替案づくりがおこ なわれた。その後第 1 ステージでまとめられた幾つかの 代替案を各町内に提示し、全町民総会、3町内で合同説明 会を行うなどして、代替案に対する住民の意見をくみ上 げた。

第 2 ステージではその住民の意見を考慮しながら基本 案づくりがおこなわれ、その基本案を基に住民説明会が 実施された。

第 3 ステージでは実施案づくりがおこなわれ、2000 年 夏にその実施案どおりの交通規制が実施され、また電柱 整備なども開始された。

その後、施工状況を見て異議を唱える住民が多数現れ たので説明会が開かれた。

第 4 ステージでは異議者の中から数人が代表して特別 参加という形で協議会に加わり、接点を探しつつ論議を
重ねた。

第 5 ステージでは順次、施工計画と実施報告がおこな われており、現在に至っている。

道路・標識等の整備事業は 2004 年 12 月に旭ヶ丘県営 住宅周辺を残しほぼ終了している。その後、地区住民と 地区外の道路利用者を対象にアンケート調査、交通量調 查、走行速度調査が行われた。

\section{4. 対立点とその合意形成のプロセスについて}

協議会議事録を整理することで、様々な論点を把握す ることができた。ここではその中で特に論議されたもの として、(1)ふれあい道路におけるハンプ改良問題、(2)才 アシスロードにおける電柱・樹木・ポールを用いた歩車 分離の問題を取り上げ、それぞれの協議プロセスと合意 形成に至る契機となった発言や行動について考察した。

\section{（1）ふれあいロードにおけるハンプの問題}

\section{a) 整備前、整備後の状況}

ふれあいロードは事業以前に一通り整備されていた。 通過車両の速度を減ずる目的で、台形ハンプを設置した が、苦情者が出たため現在はスピードセーブ工法に改良 されている。苦情の内容は、車が通過する際に生じる車 とハンプとの摩擦音がひどくうるさいという内容であっ た。

b) 合意形成までのプロセス

合意形成までのプロセスを図ー 3 に示す。

台形ハンプを設置することが決定(第 10 回協議会)

施工

減速効果が不十分(第 11 回協議会)

対策について势議

役所に不信感を抱いていた苦情者の出現

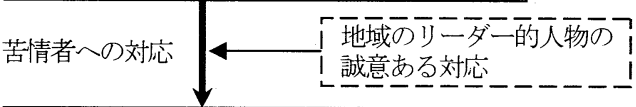

改善策としてスピードセーブ工法の提案

(第 19 回協議会)

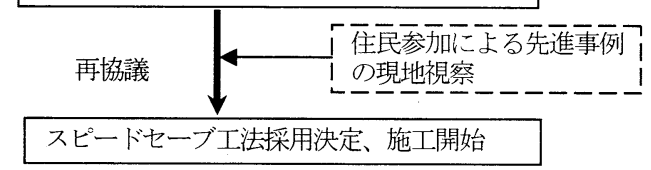

図ー3 ハンプに関する合意形成のプロセス

c) 合意形成のポイント

以上のような協議プロセスによって、現在スピードセ 一ブ工法が施工されている。このプロセスの中での合意 形成促進のためのポイントは 2 点あったと考えられる。 
(1) 地域におけるリーダ一的人物の存在

若久地区の場合、協議会会長でもある若久公民館館長 が地域のリーダー的人物にあたる。公共施設の整備にお いては、行政側のみの対応だけでは住民の理解が得られ ない局面がときおり現れる。このような場合、地域に信 頼の厚いリーダー的人物の存在は大きく、こうした人物 が協議の過程に加わり、熱意を持って反対者との交渉に 当たったことが、今回の合意形成の促進において重要な 要素となったと考えられる。

(2) 実際の経験を通しての判断

専門的知識の情報が得にくく、特に未経験の場合、一 般住民にとっては、行政や専門家の言葉だけの説明では 十分な理解は難しい。本事業において、特にスピードセ 一ブ工法の説明時には、地域住民に対し工法の PR ビデ オを上映したり、施工事例の現地視察等を通して、住民 のより深い理解が得られ、住民自らがより適切な判断を 下すことができる状況をつくり出してきた。その結果、 ハンプ改良策に対する地域住民からの了承を得ることが できたと考えられる。

本事業は社会実験ではないが、事業実施のプロセスの 中にやりかえを通してフィードバックの手続きを積極的 に導入しようと試みている点で、社会実験的な性格を有 していた。社会赛験には、サイレントマジョリティを含 む地域住民を、強要することなく流れに沿って分かりや すく参加させることができ、また全体の合意形成の促進 を図るという効果があるといわれているが、本例はまさ にこれを実践したものといえる。

\section{（2）オアシスロードにおける歩車分離の問題}

\section{a）整備前、整備後の状況}

オアシスロードは、幅員が狭い上に通過車両が両方向 から進入し、さらに電柱も道路両側に乱立していた。そ のうえ歩行者の安全は確保されておらず、歩車分離等に よる歩行者優先のみちづくりが最重要課題であった。

\section{b) 合意形成までのプロセス}

合意形成までのプロセスを図ー4に示す。

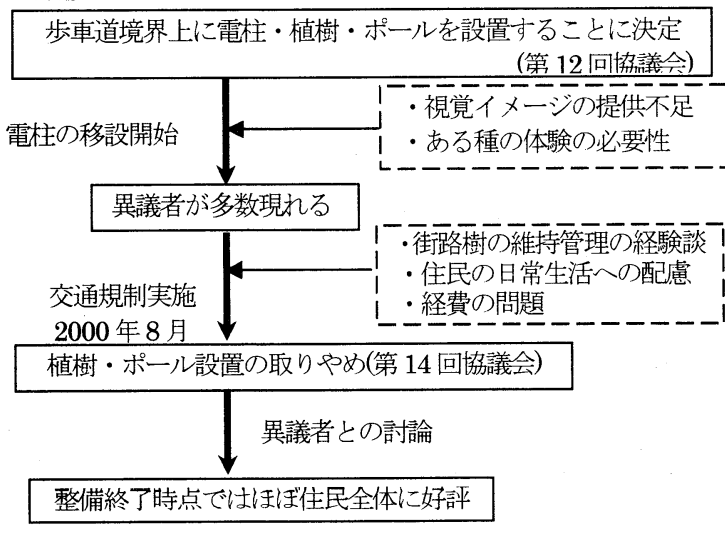

図-4 電柱・植樹・ポールに関する合意形成のプロセス

\section{c）合意形成のポイント}

現在は歩車道境界上に電柱のみが残された状況である。 この問題に関する合意形成のポイントとして次の 4 点を 挙げることができる。

\section{(1)経験談 (植樹)}

議論当初から残っていた街路樹の維持管理の問題に関 して、実際に他所で経験した町内会長が維持管理の継続 の困難や、生活上の支障の可能性などを協議会で指摘し たことが契機となり、それまでの決定が覆され、植樹は 実施しないという最終合意に至った。

(2)地域内住民一の配慮（ポール）

オアシスロードに歩車分離のためのポールを設置する ことは、歩行者、特に通学する小・中学生やお年寄り等 の交通弱者の安全を確保寸るといった点で効果的ではあ る。しかし、地域内住民の生活があまりに不便になる（自 動車の入出庫等）のでは、反対者が増え、住民の事業一 の関心・参加意欲が損なわれる可能性が高い。そうした 判断から、最終的には地域内住民の利便性に配慮し、ポ 一ルの設置を諦めた。

(3)整備内容の視覚イメージを明示すること（電柱） イメージできないものに対する不安感が地域住民を反 対者へと変えてしまうことがある。工事の途中とはいえ 「電柱道路」と挪揄される状態をみて、完成形に対寸る 疑問・不安を覚え異議を唱えたものと考えられる。しか しここで、電柱移設後には異議者の大半が異議を唱えな くなった事実に着目する必要がある。これは住民が整備 後のイメージを整備中には想像することができず、完成 後に目で見てはじめて理解できたためであり、しかもそ の整備状況が想像以上に良く、反対する理由がなくなっ たものと思われる。(なお現在も反対している住民は少数 ながら存在する。)

以上から整備後の状況のリアルな視覚イメージに関す る情報提供が不足していたことが指摘できよう。

(4)ある種の体験の必要性

前述のふれあいロードのように、施工事例の現地視察 や社会実験等を通して、住民により深い理解を促し、住 民自らがより適切な判断を下寸ことができる状況をつ くり出す必要があったと思われる。

\section{5. 事業の評価}

\section{（1）交通量 - 交通事故数から見る整備効果}

\section{(1) 交通実態調査結果}

福岡市南区役所は、事業実施前後に交通状況調查を 実施し、それらの比較を通して、交通規制に関する事 後評価を行った。交通実態調査は、事業前の1998 年 2 月 17 日上、事業後の 2004 午 9 月 7 日に行われた。観 測時間は、それぞれ昼間の 12 時間(7 時〜 19 時)とし、 
調査項目はクロスロード、ふれあいロー ド、オアシスロード、なかよしロード、 スマイルロードの計 10 地点における単 路自動車交通量調査、ふれあいロードの 2 地点における車両走行速度調査であ る。また、整備前にはナンバープレート 追跡調査も行なわれており、事業前の通 過交通は 6300 台であったことがわかっ ている。事業後には単路自動車交通量の みの調査が行われた。以上の結果を表一 3に示す。地区内での総観測交通量は約 5600 台減少しているが、調査時間が 12 時間と長いことから、地区内交通も含め てすべての自動車交通が各 2 回カウント されていることを考慮すると、実際に走 行した自動車数は観測された交通量の 1／2であり、地区内で確認された実際 の減少台数は約 2800 台であると推定さ れる。さらに、地区内居住者の交通量は 事業前後で大きな増减はないと仮定し、 減少した 2800 台の大半を通過交通とみなせば、交通規制 によって通過交通の約 44\%が削減されたことになる。一 方、交通規制を行わなかった路線では大きな変動は見ら れなかった。以上の結果より、「交通規制による地区外か らの通過交通の削減」という目標は達成されたと言える。

車両走行速度調查の結果を図一 5 に示す。この調査は ふれあいロードにおけるスピードセーブ工法の効果を調 べるためのものである。施工直後の 2002 年の速度調査で は施工前と施工後の走行速度においては $3 \sim 4 \mathrm{~km} / \mathrm{h}$ の 速度低下が確認されているが、施工後 2 年経過した 2004 年の調査では施工前の走行速度及び速度分布に戻ってい ることが確認された。アンケート調査でもスピードを出 す車が多いとの意見も寄せられている。これは無信号で あったふれあいロードの交差点に、事業後は黄色点滅の 優先信号 (交差側は赤点滅信号) が設置されたことに大 きな原因があると考えられている。

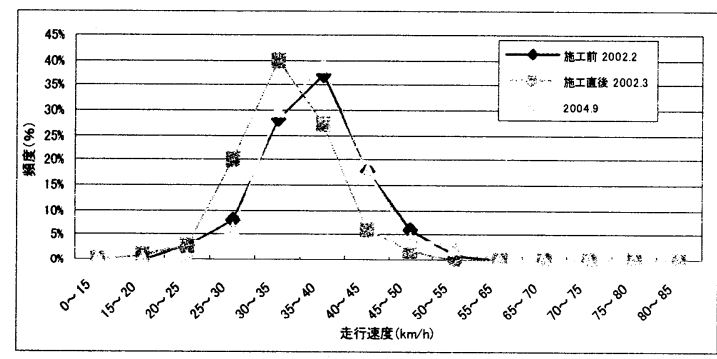

図ー 5 走行速度の比較（ふれあいロード）

(2) 交通事故発生状況

交通事故件数の比較表を表一 4 に示す。なお、交通規
表 -3 単路自動車交通量調查結果

\begin{tabular}{|c|c|c|c|c|c|}
\hline 連番 & 路線名 & 形状 & $\begin{array}{c}\text { 事業前平日12H } \\
\text { 自動車交通里 }\end{array}$ & $\begin{array}{c}\text { 事業後平日12H } \\
\text { 自動車交通量 }\end{array}$ & $\begin{array}{l}\text { 增減 } \\
\text { (台数) }\end{array}$ \\
\hline 1 & 2ロスロロ & 单路部 & 812 & 501 & $\Delta 311$ \\
\hline 2 & วロスロード2号 & 单路部 & 624 & 615 & $\Delta 9$ \\
\hline 3 & 2ロスロード3묵 & 単路部 & 1,442 & 1,535 & $\triangle 93$ \\
\hline 4 & วロスロード4号 & 単路部 & 2,140 & 833 & $\Delta 1,307$ \\
\hline 5 & ふれあいロード西側 & 单路部 & 3,210 & 3,272 & $\triangle 62$ \\
\hline 6 & ふれあいロード東側 & 単路部 & 6,052 & 4,529 & $\Delta 1.523$ \\
\hline 7 & オアシスロード東側 & 単路部 & 1,992 & 173 & $\Delta 1,819$ \\
\hline 8 & オアシスロード西側 & 単路部 & 1,220 & 397 & $\Delta 823$ \\
\hline 9 & なかよしロード & 单路部 & 566 & 469 & $\Delta 97$ \\
\hline 10 & スマイルロード & 単路部 & 915 & 1,046 & $\triangle 131$ \\
\hline \multicolumn{3}{|c|}{ 地区内合計 } & 18973 & 13,370 & 5,603 \\
\hline
\end{tabular}

表 -4 事故発生件数の比較

\begin{tabular}{|c|c|c|c|c|c|c|c|c|c|}
\hline \multicolumn{3}{|c|}{ 規制前(期間: $: 4$ 年7个月） } & \multicolumn{6}{|c|}{ 規制次(3年5-月） } & \\
\hline$\left.H 9 \begin{array}{l|l}H 11 \sim H_{112} \\
(7 \text { 月以前 }\end{array}\right)$ & 件就 & 平平坊 & 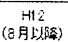 & H13 & $\mathrm{H} / 4$ & H15 & 非效 & 年平均 & 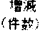 \\
\hline 12 & 37 & 81 & 0 & 5 & 5 & 2 & 12 & 35 & $\Delta=E$ \\
\hline 2 & 7 & 1.5 & 0 & $a$ & is & b) & 9 & 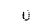 & $\Delta$ \\
\hline 0 & 4 & פי & 0 & 0 & 1 & : & i & 93 & $\Delta$ \\
\hline 11 & 23 & 5 & 0 & 5 & 3 & 5 & 13 & 38 & $\Delta 10$ \\
\hline 22 & 55 & 12 & 3 & 17 & 14 & 14 & 48 & $: 4$ & $\mathbf{A}_{i}$ \\
\hline 6 & 14 & 3.1 & 0 & 4 & 6 & 4 & 14 & 41 & \pm 0 \\
\hline 7 & 27 & 59 & 0 & 3 & 3 & 7 & 13 & 38 & $\mathbf{A}_{14}$ \\
\hline 6 & 25 & 55 & 0 & $?$ & $\hat{\mathrm{B}}$ & 4 & 17 & 5 & $\Delta 8$ \\
\hline 5 & 23 & 5 & 3 & 6 & b & 3 & 22 & 84 & $\Delta 1$ \\
\hline
\end{tabular}

制は $\mathrm{H} 12$ 年 8 月から開始されている。ゾーン外側の幹線 道路である清水干隈腺(大池通り)の各交差点での事故件 数は、規制前と規制後に大差は見られないが、地区内の 各道路については大幅に減少している。通過交通量の減 少と関連して交通事故も減少しており、「安全性の確保」 という目標は達成されている。

\section{（2）地区住民と道路利用者による評価}

事業終了後に全体を振り返り、事業中に見えなかった 問題点を確認寸るため、協議会が中心となって地区住民 2066 人・児童 275 人・生徒 160 人、及び周辺地域の道 路利用者としてタクシー運転手 75 人など立場の違う 様々な人を対象にアンケート調査を行い、それぞれ 280 人、 249 人、 27 人、 49 人から回答を得た。調查内容は対 象者ごとにそれぞれ異なっており、地区住民には、安全 性の向上度や歩きやすさに加え、協議会の認知度などを 調査した。児童・生徒には、安全性の向上度や歩きや寸 さを中心に、地区に対する意見などを調査した。タクシ 一運転手には、車の利用しやすさなどを中心に調査した。 その結果を分析して評価を行った。

(1)事業への関わり及び認知度等の調査

本事業は住民とともに進めていくことを目標に掲げて いる。そこで、地区住民に対して事業に実際どのように 関わってきたかを尋ね、その結果を表一 5 に示した。こ の結果より、全く関心を示さなかった人が $20 \%$ になり、 その他は工事の進展や、協議会での話し合いの進展を見 守っていたといえる。以上のことより住民の事業への関 心は高かったといえる。 
一方、表一6の結果から、約 7 割の住民は主に回覧板 や公民館便りを情報源として利用していたことがわかる。 しかしながら、これらを利用していた住民の約 $65 \%$ は、 協議会の存在を知る程度の認知にとどまり、その活動内 容までは伝わっていないことがわかった。その結果、後々 になって聞いていないという不満を持つ住民も現れ、 双方の情報伝達の認識に差が生じていた。また同地区に 居住していない地権者には情報が伝わっていなかったた め、その中からも異議者が現れたことも反省すべき点で ある。このことから、回覧板や公民館便りは、住民の末 端まで配布されるという利点を有する一方で、問題点と して、一方的な情報であること、情報の範囲が地区内だ けに限られること、掲載スペースに制限があること、情 報の画一化を招く恐れがあることなどが考えられ、これ ら型通りの情報提供だけでは不十分であるといえる。一 方で、人数は少ないものの、説明会などの協議会側と住 民側が直接意見交換する場で情報を得ていた約 8 割の住 民は、協議会の活動内容まで認知していたということが いえる。以上のことから、合意形成のためには情報の双 方向的な伝達方法の確立・改善を様々に検討・工夫する ことが必要であるといえる。

(2)事業への民意の反映

住民参加型の本事業では、事業に住民の意見がどの程 度反映されているかを知ることは重要である。住民に対 して、事業に住民の意見が反映されているか在尋ねた結 果を表一 7 に示す。その結果、「事業への住民意見の反映」 については、住民から肯定的な回答が約 7 割近くを占め、 高い評価を得ていると判断できる。一方で、自由記入闌 では、「ごく一部の人の意見だけで物事が進んでしまった のではないか、「意見があってもどこに言えばよいのか わからない」という意見もあった。住民参加型の施設づ くりの成功のためには、少数意見をくみ上げ、事業に反 映させていく仕組みを確立していかなければならない。

(3)事業に対する評価

a)地域住民、児童

本事業によって地区での生活がどのように変わったと 受け止めているのか、住民と地区の児童・生徒へのアン ケート結果は表－8、表一 9 のようになった。表一 8 よ り本事業によって 172 人(住民全体の $74 \%$ )が住みやすく なったと感じており、事業の成果については評価されて いると判断される。また、表一 9 より 97 人(児童全体の $51 \%$ )があまり変わらないと回答している。これについて は、小学生が大人ほど道路整備に関心がないこと、空間 認知が十分に発達していないこと7)などが原因と考えら れる。

\section{b)周辺地域の道路利用者(タクシー運転手)}

本事業によって、車で地区内を通行する人たち(タク シードライバー) はどのように感じているのかを調查し

表一 5 事業への関わりについて

\begin{tabular}{|c|c|}
\hline & 全体 \\
\hline 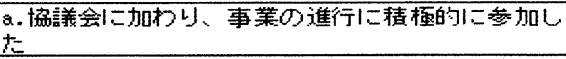 & 10 \\
\hline 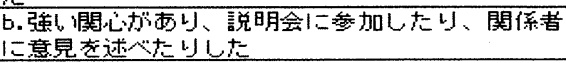 & 19 \\
\hline 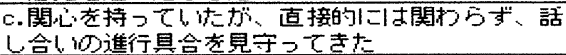 & 89 \\
\hline $\begin{array}{l}\text { d.それはど関心は無かったが、工事の進展は見 } \\
\text { 守ってきた }\end{array}$ & 92 \\
\hline e.全く開心が無く、上く知らない & 53 \\
\hline
\end{tabular}

表一 6 住卞の主な情報源亡協議会活動に対する理解の関係

\begin{tabular}{|c|c|c|c|c|c|}
\hline & $\begin{array}{l}\text { 具体的な内容 } \\
\text { まてよく知って }\end{array}$ & $\begin{array}{l}\text { 存在しおおまかな活 } \\
\text { 動内容は规っていた }\end{array}$ & $\begin{array}{l}\text { 存在|さ㚘一ていたが、 } \\
\text { 活動内容は规らなかっ。 }\end{array}$ & 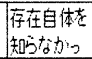 & 計 \\
\hline 町内0回覧板 & 5 & 34 & 54 & 26 & 119 \\
\hline 公民部便 & 3 & 13 & 15 & 7 & 38 \\
\hline Kから聞儿T & 1 & 4 & 9 & 4 & 18 \\
\hline 説明会への参加 & 5 & 15 & 4 & 1 & 25 \\
\hline マスコ㹸通て & 0 & 0 & 1 & 3 & 4 \\
\hline ０他 & 4 & 5 & 2 & 5 & 16 \\
\hline 計 & 18 & 71 & 85 & 46 & 220 \\
\hline
\end{tabular}

た。その結果を 表 -7 住民意見の反映について 表一10に示す。 同地区の道路を 利用するタクシ 一運転手から見 ても、当該地区 の道路規制と道 路整備のあり方 については、あ る程度基本的な 理解が得られて いると判断され る。一方、自由 記入欄では「自分 たちの地区のこと しか考えていない のではないか」と いう意見もあった が、こうした意見 に対しては、事業 の目的を十分に理 解してもらうべく、

\begin{tabular}{|l|r|}
\hline & 全体 \\
\hline a. 十分反映されている & 25 \\
\hline b. ある程度反映されている & 129 \\
\hline c. 反映されているが不十分である & 53 \\
\hline d. 反映されていない & 17 \\
\hline
\end{tabular}

表一8 地域住民の評価

\begin{tabular}{|l|r|}
\hline & 全体 \\
\hline a. 大変住みやすくなった & 50 \\
\hline b. 住みやすくなったが満足はできない & 122 \\
\hline c. 以前とあまり変わらない & 49 \\
\hline d. かえって住みにくくなった & 12 \\
\hline
\end{tabular}

表ー9 オアシスロードについて(児童)

\begin{tabular}{|l|c|}
\hline & 全体(児童) \\
\hline 歩道が出来て歩きやすくなった & 53 \\
\hline 比較的歩きやすくなった & 34 \\
\hline あまり変わらない & 97 \\
\hline 歩きにくくなった & 6 \\
\hline
\end{tabular}

表一10 タクシー運転手の評価

\begin{tabular}{|c|c|}
\hline & 全体 \\
\hline 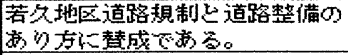 & 28 \\
\hline 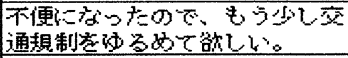 & 11 \\
\hline 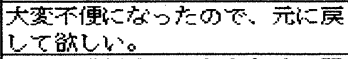 & 2 \\
\hline $\begin{array}{l}\text { あまり通行することもなく、関 } \\
\text { 宁がない。 }\end{array}$ & 5 \\
\hline その他 & 4 \\
\hline
\end{tabular}

地区外に対しても積極的に PR していく必要がある。

(4)事業後の協議会

事業後に実施されたアンケート結果を受けて、2004年 12 月 13 日に行政・住民・専門家が一堂に集まって第 28 回調整協議会が開催された。その場で本稿で示している 事業評価、アンケートの集計結果が公表され、さらに、 改善点などの意見がよせられた。改善点については、今 後、必要性を検討の上、コミュニティゾーン形成事業完 了後も、一般事業として実施していくことが確認された。 このように、寄せられた改善点について、以後の事業で 実施するといら柔軟で積極的な対応は、これまでの協議 
会の長いプロセスで培われた行政と住民の信頼関係から 生まれたものであると評価できる。

\section{6. 結 論}

本研究では、長期に渡って重ねられた調整協議会のプ ロセスを、協議会議事録の整理、関係者へのヒアリング、 および事後のアンケート調查を主として、住民参加のブ ロセスがどのように進行し、また対立点に対し合意形成 がどのように図られたかを分析した。

本事例は、当初相当な利害衝突で合意形成が困難に思 われたが、長期にわたる協議会の積み重ねや協議会会長 をはじめとする担当者が異議者と粘り強く話し合った結 果として合意が成立し、予想以上の安全性や快適性を得 ることができ、事業自体も概ね好感を持たれている。こ のことは、交通量や事故件数などの客観データからの評 価に加え、事後評価アンケートの結果として、本事業の 進行方法、及び道路整備のあり方に対して、地域住民や 周辺地域の道路利用者から一定の理解と評価を得ている ことからも明らかである。

また、本事例では、事業の運営方法についての事後評 価として、協議会の活動に対する認知度や情報伝達など の事柄について、事業の身近にいた人にしかわからない 内容を通して主観的な意識評価も加えている。これによ って、事業中に見えなかった反省点を確認し、今後の参 加型施設づくりのために、本事業の経緯や体験を明確な 形で残すことが可能になった。

本事例の分析結果として、参加型の社会基盤整備にお ける対立点の合意形成の促進には、その地域におけるリ 一ダ一的人物の存在が必要なこと、実際の体験（ある種
の社会実験）を通して判断することが必要なこと、長い プロセスをともにすることによって、行政と住民の間に 信頼関係を築きうること、および、情報の伝達の工夫や 双方向的な情報交換と共有が重要であること、などが明 らかになった。

今後の課題として、(1)同事業における他事例との比較、 (2)他の参加型社会基盤づくりとの比較が残されている。 今後はこうした課題に取り組み、合意形成の要件につい てより一般性を持たせることが必要である。

\section{参考文献}

1)浦山・小川·神吉:「住民参加による地区幹線道路の計画立案プロ セスにおける合意形成に関する事例研究 2001 年度第 36 回日 本都市計画学会学術研究論文集pp553-558

2) 山岡·磯部:「コミュニティゾーン形成事業の住民参加及び身近さ に関する研究一名古屋市長根台地区を事例にー」1999 年度第 34 回日本都市計画学会学術研究論文集pp805-810

3)花田・川村·澤田·濱村:「コミュニティゾーンにおける安全対策の 手法とその效果について」第 18 回交通工学研究発表会論文報 告集pp 77-80

4)社団法人 交通工学研究会:「コミュニティ・ゾーン形成マニュアル 一地区総合交通マネジメントー」1996 年 5 月

5)社団法人 交通工学研究会:「コミュニティ・ゾーン実践マニュア ル」2000年 7 月

6)菊池·外井·坂本·梶田:「住民参加型の道空間づくりにおける合意 形成のプロセスについて〜福岡市南区若久地区コミュニティゾー ン形成事業を例にして〜」2003 年度土木学会西部支部研究発 表会

7) 長山·矢守編:応用心理学講座6「空間移動の心理学」1992 年 11 月 20 日

住民参加型の道空間づくりにおける合意形成のプロセスについて*

江夏量** - 外井哲志 $* * *$. 坂本紘二**** - 菊池康昭 $* * * * *$ - 梶田佳孝******末久正樹******* 本研究は、若久地区コミュニケーション形成事業を事例として、長期に渡って重ねられた調整協議会のプロセスを、 協議会議事録の整理を主たる手段として把握することによって、住民参加のプロセスがどのように進行したか、対立 点に対しよ゙のように合意形成が図られたかを分析したものである。具体的には発見できた対立点を挙げ、その合意形 成プロセス、また合意形成促進のために必要な事項について考察した。また、本事業の特質を述べた後、進行上の課 題を挙げ、原因を検証するとともに、問題解決を促すと考えられる方策を提案し、その効果を考察した。最後に、本 研究によって明らかになったこと、提案したことをまとめた。

The Process of the Agreement on Street Space Planning by the Residents By Ryo ENATSU, Satoshi TOI, Koji SAKAMOTO, Yoshitaka KAJITA, Masaki SUEHISA This study is on the project of forming the community zone at Wakahisa district in Fukuoka-city. We researched the process of residents participation and agreement by analyzing the conference minutes and interview. As the special feature of this case study, the conferences that were held great number of times, the familiarity by naming streets, the analysis from children's viewpoint, and the reconstruction of streets, are mentioned. It became clear that existence of the leaderperson of the area, judgment through the experiences, visualizing the image of facilities, mutual communication, and sharing of information are required for promotion of agreement. 